\title{
"The role of knowledge management in organizational performance: case study of University of Malang, Indonesia"
}

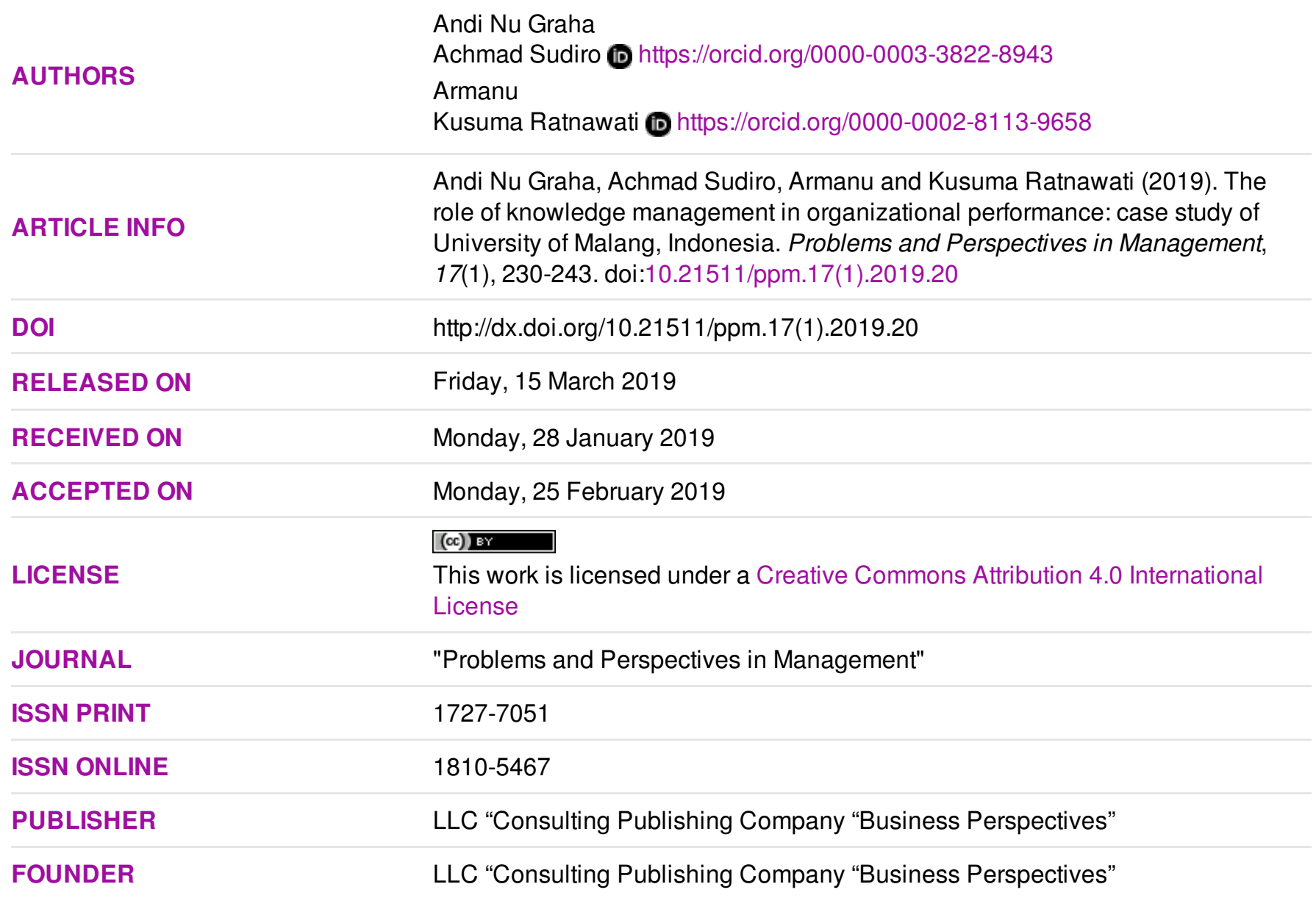

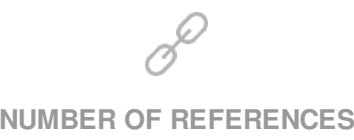

47
NUMBER OF FIGURES

1
NUMBER OF TABLES

4

(C) The author(s) 2022. This publication is an open access article. 


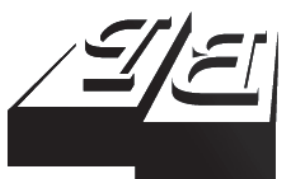

BUSINESS PERSPECTIVES

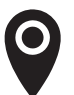

LLC "CPC "Business Perspectives" Hryhorii Skovoroda lane, 10, Sumy, 40022, Ukraine

www.businessperspectives.org

Received on: $28^{\text {th }}$ of January, 2019 Accepted on: $25^{\text {th }}$ of February, 2019

(C) Andi Nu Graha, Achmad Sudiro, Armanu, Kusuma Ratnawati, 2019

Andi Nu Graha, Student, Doctor Program of Management Science, University of Brawijaya, Indonesia.

Achmad Sudiro, Professor, Faculty of Economics and Business, University of Brawijaya, Indonesia.

Armanu, Professor, Faculty of Economics and Business, University of Brawijaya, Indonesia.

Kusuma Ratnawati, Doctor, Faculty of Economics and Business, University of Brawijaya, Indonesia.

\section{(c) (i)}

This is an Open Access article, distributed under the terms of the Creative Commons Attribution 4.0 International license, which permits unrestricted re-use, distribution, and reproduction in any medium, provided the original work is properly cited.
Andi Nu Graha (Indonesia), Achmad Sudiro (Indonesia), Armanu (Indonesia),

Kusuma Ratnawati (Indonesia)

\section{THE ROLE OF KNOWLEDGE MANAGEMENT IN ORGANIZATIONAL PERFORMANCE: CASE STUDY OF UNIVERSITY OF MALANG, INDONESIA}

\begin{abstract}
The present study puts forward a model that examines variables of human resources management practices, organizational culture, knowledge management and organizational performance. By this model, it intends to explore the effects of human resources management practices and organizational culture on organizational performance. Particularly, it intends to find out their relationship with knowledge management as a mediator. The research applies SmartPLS for data analysis, with 163 respondents by means of saturation sampling technique. The results display several facts. First, both HRD practices and organizational culture have significant effects on knowledge management. Second, while knowledge management and organizational culture have a significant effect on organizational performance, HRD practices do not significantly affect organizational performance. It makes knowledge management only serve a partial mediation between human resources management practices and organizational performance, and serve a full mediation between organizational culture and organizational performance.
\end{abstract}

\section{Keywords}

human resources management practices, organizational culture, knowledge management, organizational performance

\section{JEL Classification $\quad$ M20, O15}

\section{INTRODUCTION}

Organizational performance has been a prerequisite for any university to nuance their excellence. One important component of performance is quality. To make sure the achievement of quality standards among universities, Indonesian government has formed an office with a specialized task of assuring quality of universities. This office was named as National Accreditation Agency for Higher Education (BAN-PT), which issues accreditation for each university reflecting quality, performance and eligibility to provide higher educational service to public.

Knowledge management has been found as a key buzzword for heightened organizational performance, though several researches prove otherwise. It is especially so for universities that operate in knowledge and science sector. Qualified knowledge management might reflect the quality of human resources and resulting quality of the products, that is the graduates. This quality is evident through the number of their journal writings, scientific products and the labor market absorption of the graduates. 
HRD practices are one major determinant of knowledge management. They include the recruitment and development of human resources that can be exploited for organizational purposes, including organizational performance through knowledge management. The right HRD practices for example buffer information and knowledge sharing that allows for a better knowledge management. The practices range from organizational policies, methods, and systems considered as best ways to affect people' behaviors, attitudes, and their performance for the interest of organization.

Another major determinant of knowledge management is organizational culture. Any dominant type of culture an organization adheres could support or hinder knowledge management. Some type is considered to give more support, and others less support or even hinder the efforts involved in knowledge management depending on the nature of environment and competition an organization is facing.

The present research explores university performance in terms of human resource management practices and organizational culture. Regarding human resource management practices, main key to uplift organizational performance is to make sure that lectures support organizational focus on productivity, service, and quality (Arwildayanto, 2013). Regarding organizational culture, Tseng (2010) held that for an organization to have a sound performance, it should develop culture that set the way for exchange traffic of ideas, knowledge, and experiences.

Previous research on the relationship between human resources management practices and organizational performance provides mixed results. Moideenkutty et al. (2011), Amin et al. (2014) and Saeed et al. (2013), among others, support the idea that human resources management practices have an effect on organizational performance, while Singh (2004), Björkman and Budhwar (2007), and Vivares-Vergara et al. (2016) prove otherwise. Other works such as Lin and Kuo (2007), Yazhou and Jian (2012) revealed that human resources management practices have indirect effect on organizational performance.

Previous research on the relationship between organizational culture and organizational performance also features mixed results. Quresh et al. (2010), Idris et al. (2015), Naranjo-Valencia et al. (especially for adhocracy and clan culture, 2016), Tseng (2010), for example, support the relationship between organizational culture and organizational performance, while Naranjo-Valencia (2016) shows that hierarchy has a negative effect on performance.

The inconsistent relationship between human resource management practices and organizational performance, and that between organizational culture and organizational performance give two justifications for the research. First, its replication in the context of university. Second, the exploration of knowledge management's role as mediator in those relationships. The results expectedly should clarify the nature of the relationships and enrich knowledge concerning knowledge management's role in mediating the relationships, that knowledge management plays a full role in the relationship between organizational culture and organizational performance, and a partial role between human resources management practices and organizational performance.

\section{THEORETICAL REVIEW}

\subsection{Organizational performance}

Performance is the outcome achieved by organization's members (Gibson et al., 2012). According to Mahsun (2007), performance refers to extent to which a program or activity has been accomplished in order to materialize organization's objectives, targets, and vision guided by strategic planning. Homburg et al. (1999) said that organizational performance covers effectiveness in the achievement of organization's purposes, efficiency in producing output, and adaptation to changing environment.

For higher educational institution, performance can be measured by some tools. Some of them, among others, include balance scorecard, multi- 
dimensional performance model, dashboard, performance efficiency method, service profit chain, BCG matrix, success dimensions model, results and determinants model, and total quality management (TQM) (Karpagam \& Suganthi, 2010). Bayat (2011) mentioned several tools of measurement such as Balance Scorecard, Critical Few, Performance dashboard, and Malcolm Baldrige National Quality Award Criteria. Other measurements of performance include ISO 9000, Accreditation, Servqual, Benchmarking, Licensure, Academic Program Review, Six Sigma and others.

Today, measurement of performance for university in Indonesia follows accreditation system introduced since 1996 by National Accreditation Agency for Higher Education (BAN-PT). The recent ruling states that all higher educational institutions must have been accredited by 2013 to maintain operational license from being revoked. This ruling has made most higher educational institutions follow all accreditation rules, conditions, procedures and document this body provides. Accreditation has been introduced since 1997, and all universities should conform to its terms to maintain their image and reputation. This office makes three categories of accreditation. A category refers to quality excellence, while B category refers to good quality, and $\mathrm{C}$ as average that might erode universities' reputation. All universities attempt to follow government standards in order to be eligible at least for B category. However, from existing 10,587 departments following BAN-PT's accreditation process, $36.10 \%$ of them fall with in "C" (Amir, 2010).

The institution imposes 7 performance standards all universities should conform to in order to get recognition from government and public:

1) vision, mission, purposes and achievement strategies;

2) governance, leadership, management system and quality assurance;

3) students and alumni;

4) human resources;

5) curriculum, studying system and academic atmosphere;

6) funding resources, facilities and infrastructure, and information system;

7) research, public service and cooperation.
The accreditation process involves experts who are knowledgeable on ways to evaluate management of department and university as a whole. They work collegially in a group called assessor team.

\subsection{Human resources management}

Dessler (2011) defines human resources management as practices and policy managers make in staff recruitment, selection, training, reward and evaluation. According to Randhawa (2007) human resource management are activities that cover planning, organizing, directing, and controlling of procurement, compensation, integration, maintenance, and employee placement to achieve organizational, individual, and social goals. Human resource management practices covering planning, recruitment and selection are commonly performed by personnel units; human resources development sectors focusing on training and career planning and development; compensation unit focusing on direct financial compensation and non-financial compensation; working unit focusing on safety and health; and social relationship (Mondy, 2010).

Human resources management according to Mathis and Jackson (2006) is a design of formal systems in an organization to ensure the exploitation of human talent in an effective and efficient manner to achieve organizational goals. Quresh et al. (2010) identify five key HRM practices, that is training and development, recruitment and selection, compensation and reward, performance evaluation, and employee participation. Quresh et al. (2010) categorize HRM practices into selection system, training, job definition, system of performance evaluation, compensation system, and system of career planning and employee participation.

Suwatno and Juni (2013) hold that human resources are related to all aspects pertaining to how people work and are managed in the organization. Human resource is a valuable asset, and it would function best when developed and driven by right and consistent policy that engenders commitment, allowing for employees' willingness and thus flexibility to adapt to organization's interests. The policy includes ways to develop human resources, to relate human resources to organizational social responsibility, knowledge management, organi- 
zational development, performance management, learning and development, balance management, employee relationship, employee welfare, health and safety, and human resource supply.

Human resources management covers policies, practices, and systems pertaining to attitudes, behaviors, and staff performance. Human resources are made up of four dimensions, that is human resource environment management, human resources recruitment and preparation, human resources evaluation and development, and compensation to human resources.

Human resources practices in Indonesian universities follow national guidance that requires lecturer to perform three obligations called Tri-Dharma. They include teaching, research, and public service. These three obligations are designed as an integrated circle, which is complementary in nature, and not mutually exclusive. The quality of lecturers is reflected from their research and resulting internationally published journals, could teach with materials from their research results including new ideas, concept, theories and findings that enrich existing literature, from which the benefits and contributions could be proven from its public service, that is its real application in the society. By this way, lecturers are not lone learners that live separately from society, and its contributions are continuously evidenced and funneled to society, both academic and common.

\subsection{Organizational culture}

Robbins and Timothy (2008) define organizational culture as a meaning system shared by the members that differentiate their organization from others. Schein (2004) defines organizational culture as a dynamic force in an organization spinning, developing and drawing in an interactive manner molded by prevailing attitude and behavior. According to Uha (2013), organizational culture refers to values guiding people's behavior to the achievement of organizational vision, mission and purposes. Thus, culture serves to direct human resources to the achievement of organization's vision, mission and goals. Wibowo (2011) holds that organizational culture is basic philosophy of the organization containing faith, norms, shared values that determine how to behave in organization.
Pinho et al. (2014) make four types of cultural categories:

1) clan culture, emphasizing solidity, participation and team-work;

2) adhocracy culture, emphasizing values of entrepreneurship, creativity and adaptation capability;

3) hierarchical culture, emphasizing order and rules;

4) market culture, emphasizing competitiveness and market domination.

Adhocracy culture. It comes from the word ad hoc, referring to team-works with contemporary, specialized and dynamic duties. Adhocracy is a highly dynamic culture, with spirit of creativity and entrepreneurship. Market culture exists in an organization operating on market mechanism principle. It is mainly characterized by transaction, cost and competitiveness and production goals. Success is evaluated from market share and market leadership. Hierarchical culture represents highly formalized and structured procedures. They serve as internal control by means of rules and specialized functions where efficiency and organization' goal achievement is prioritized. Clan culture is a family-like culture, with intimate, sharing, and emotional characteristics, with emphases on team-work, participation and consensus. Organizational leader is viewed as mentor or respected elder. Loyalty or tradition serve as a binding between members.

It is among few researches that examine the relationship between organizational culture and organizational performance in the university context, especially in Indonesia. It is interesting, as most Indonesian universities are still in teaching type, while one indicator for performance is research. National obligations for lecturers that include teaching, research, and public service are not also yet contained in all universities' culture.

\subsection{Knowledge management}

Knowledge management is a pivotal issue in business, industrial and educational worlds. It refers to processes where organization creates, arrang- 
es and shares knowledge, and serves as a main source of sustainable organizational competitive edge (Hatch \& Dyer, 2004). According to Prabowo (2010), university commonly applies knowledge management in four main processes, that is: product and curriculum process, administration service process, student and alumni service process, and public service process.

According to Serban and Luan (2002), knowledge management is about way to make use of knowledge and ideas, which are systematically organized to the achievement of organizational efficiency, competitive edge, and innovation. The main point of knowledge management is the creation and making use of knowledge. It all depends on three things any organization should possess, that is technology, organizational structures, and other specific knowledge means (Adhikari, 2010).

According to Adhikari (2010), knowledge management is related to exploitation and development of knowledge asset to sustain the achievement of organization's target. The essence is that knowledge is an asset which can bring values to organization if managed properly. Thus, knowledge management is a structured activity to develop organization' s capacity in procuring, creating, sharing and applying tacit and explicit knowledge in attempt to achieve sustainability and superiority.

It is interesting to find out the effect of knowledge management on organizational performance in Indonesian universities, as a research has confirmed that knowledge management in Indonesian universities is mostly still in limited performance (Absah, 2008), instead of that fact that its performance in some universities allows for smooth transition from knowledge institution to learning institution. Its right performance would provide universities a better leverage in fulfilling demands in globalization era.

\subsection{Hypotheses development}

\subsubsection{Relationship between human resources management practices and organizational performance}

Some research supports the relationship between human resources management practices and or- ganizational performance. It includes for example Moideenkutty et al. (2011), Amin et al. (2014), Saeed et al. (2013), and others. It means that organization should pay attention to human resources management practices in order to obtain increased performance. Or human resources practices are one of ways to achieve increased performance. However, there is not yet consensus over this issue, as other research provides evidence of contrary results. For example, Björkman and Budhwar (2007) and Vivares-Vergara et al. (2016) showed that human resources management practices do not necessarily lead to organizational performance. Singh (2004) has mixed results. On the one hand, certain human resources management practices such as training and compensation system have positive and significant effects on organizational performance. On the other hand, other human resources management practices such as job definition and career planning system have negative and insignificant effects on organizational performance. Still other research emphasizes indirect effects of human resources management practices and organizational performance, for example, Lin and Kuo (2007), and Yazhou and Jian (2012).

These mixed results encourage the replication in the context of university organization. Thus, this research hypothesizes that:

\section{H1: Human resources practices have a significant effect on organizational performance.}

\subsubsection{Relationship between culture and organizational performance}

According to Tseng (2010), an organization could enjoy increased organizational performance by means of culture that paves the way for two-way interaction of ideas, knowledge, and experiences. In university context, organizational culture could heighten competitive edge that is strategic for increased organizational performance. It also provides the organization with identity uniqueness that is hard to duplicate, if not impossible, in other places. Organizational culture uplifts the principles of truth, objectivity, transparency, and independence. Thus, it can be argued that organizational culture might lead to organizational performance. 
Naranjo-Valencia (2016) found that adhocracy culture has the highest positive effect on organizational performance, followed by clan culture. However, hierarchy and market cultures have significant and negative effects. Other research such as Yesil and Kaya (2013) proved insignificant result. In their research, Yesil and Kaya (2013) confirmed that organizational culture does not necessarily lead to organization's financial performance.

These mixed results encourage the same exploration in the context of university. Thus, the research makes the following hypothesis:

\section{H2: Organizational culture has a significant effect on organizational performance.}

\subsubsection{Relationship between human resources management practices and knowledge management}

Lin and Kuo (2007) found that human resources management practices have a direct and significant effect on knowledge management capability, while Yazhou and Jian (2012) confirmed the relationship between human resources management practices and knowledge management orientation. Fong et al. (2011) revealed that human resources management practices ranging from recruitment and selection to team-work, training and development, and performance evaluation all are related to knowledge sharing. Manafi and Subramaniam (2015) showed that all human resources management practices including training, staffing, appreciation and compensation have positive and significant effects on knowledge sharing. Jimenez-Jimenez and Sanz-Valle (2013) revealed that human resources development system-oriented knowledge application is positively related to four processes of knowledge management including knowledge acquisition, distribution, interpretation and organization memory.

The present research intends to replicate the relationship in university organization context. Thus, it puts forward the following hypothesis:

H3: Human resources management practices have a significant effect on knowledge management in university organizations.

\subsubsection{Relationship between organizational culture and knowledge management}

Tseng (2010) supports the relationship between organizational culture and knowledge management. According to their research result, adhocracy culture allows a room for more conducive environment where employees can acquire knowledge and have more chances for being creative and innovative.

In the same vein, Al Saifi (2015) found that organizational culture is related to knowledge management. He applied three dimensions as composing organizational culture variable; those are artifacts, supports for organizational beliefs and values, and underlying assumptions. His research results support the evidence that organizational culture is one of ways an organization could take to achieve an increased organizational performance.

Based on above findings, the present research attempts to replicate it in the context of university organization. Thus, it makes the following hypothesis:

\section{H4: Organizational culture has a significant effect on knowledge management.}

\subsubsection{Relationship between knowledge management and organizational performance}

Besides proving relationship between organizational culture and knowledge management, Al Saifi (2015) also proved the relationship between knowledge management and organizational performance. This research is quite similar to that of Tseng (2010), where they revealed that knowledge management and organizational performance are related.

In addition to the evidence of relationship between human resources management practices and knowledge management, Yazhou and Jian (2012) also show sound relationship between knowledge management and organizational performance. Other works such as Gholami et al. (2013), Pension et al. (2013), and Valmohammadi and Ahmadi (2015) further strengthen the relationship between knowledge management and organizational culture. 
The above research confirms that knowledge management is one way, among others, that an organization could take to achieve an increased performance. Thus, the present research puts forward the next hypothesis as follows:

\section{H5: Knowledge management has a significant} effect on organizational performance.

\subsubsection{Knowledge management as mediator in relationship between human resources management practices and organizational performance}

A few researches have explored the relationship between human resources management practices and organizational performance. Lin and Kuo (2007), for example, have developed a model involving variables of human resources management, organizational learning (OL), capability of knowledge management (CKM) and organizational performance. The results confirmed that knowledge management capability has a partial mediation in the relationship between human resources management and organizational performance, as both knowledge management capability and human resources management have direct effects on organizational performance.

With a model involving knowledge-oriented management, human resources management practices, and organizational performance, Yazhou and Jian (2012) confirmed the mediating role of knowledge management in the relationship between human resources management practices and organizational performance. With the same model, Fong et al. (2011) proved the mediating effect knowledge management plays in the relationship between human resources management practices and organizational performance.

Based on previous research above, the present research makes the following hypothesis:

H6: Knowledge management mediates the effect of human resources management practices on organizational performance.

\subsubsection{Knowledge management as mediator in relationship between organizational culture and organizational performance}

Al Saifi (2015) puts forward a model putting knowledge management as a mediator in the relationship between organizational culture and organizational performance. As both organizational culture and knowledge management have significant direct effects on organizational performance, thus his model proves that knowledge management has a partially mediating effect on organizational performance.

Tseng (2010) support the findings by model that involves organizational culture, knowledge change, and organizational performance. With similar results to those of Al Saifi (2015), Tseng (2010) confirms only partial mediation knowledge change plays in the relationship with organizational performance.

Based on research results above, the present research intends to replicate in the context of uni-

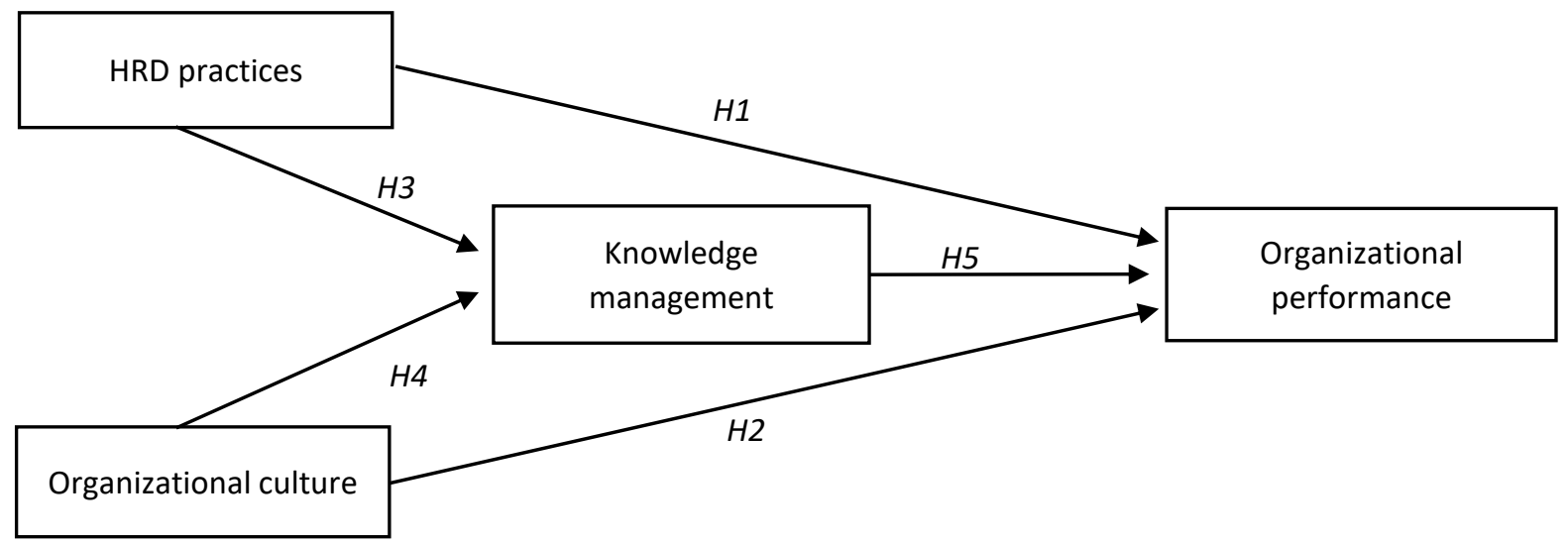

Figure 1. Research conceptual model 
versity organization in Indonesia. Thus, it hypothesizes that:

H7: Knowledge management mediates the effect of organizational culture on organizational performance.

\section{RESEARCH METHODS}

The sample covers the administrators of field studies at private colleges in Malang under PrivateCollege Coordinator Region 7 East Java (Kopertis 7). The research unit analysis is the heads of field studies at private colleges in Malang under Kopertis 7 East Java.

The research setting is Malang, as the city is known as the home of higher education composed of great universities, institutes, academies, and polytechnics. They are commonly competitive, with complete infrastructures and qualified lectures. In 2016, it has 55 private universities with 325 study programs.

Some criteria for research samples decrease the number into 26 universities with 205 field studies. The criteria are made as follows:

1) the institutions concerned have operated for more than 3 years in Malang;

2) they have field studies with $A$ and $B$ accreditations;

3) they provide easy access to information, administration and management.

It makes the study's respondents are 205. From 205 questionnaires distributed to respondents, only 163 are returned in intact and usable conditions, with accordingly $79.51 \%$ rate return.

The research applies saturation technique for questionnaire distribution, as it intends to cover all possible respondents (Sekaran, 2006). The reason behind this is that it enables for optimum generalization with small error. Generalization is important to prove the adequacy of research results.

For data analysis, it applies SmartPLS for its several advantages in relation to this nature of re- search. Unlike the more traditional maximum likelihood SEM techniques such as LISREL and AMOS (Byrne, 2013), SmartPLS requires relatively few observations. Since the current study sample size is relatively small (151), SmartPLS was found more appropriate and befitting the purpose of the current study.

\section{RESULTS}

\subsection{Socio-demography of respondents}

From compiled data, some characteristics of respondents can be evaluated for analysis purpose. In terms of age, majority of respondent are over 50 years (43.6\%). People in these ages are wise and still productive, thus can be expected for increased performance. In terms of educational background, most respondents are in master degree (65\%), followed by them doctoral degree (35\%). It indicates that respondents are commonly knowledgeable of what to do to achieve increased performance.

In terms of tenureship, most of respondents have served only one period. It means that they have chance for next period of service. It is expected that they are more knowledgeable and more equipped with future planning if they are given the second chance. Detailed description of respondents is presented in Table 1.

Table 1. Description of respondents

\begin{tabular}{|c|c|c|c|}
\hline No. & Characteristics & Frequencies & $\%$ \\
\hline \multicolumn{4}{|c|}{ AGE } \\
\hline 1 & $\leq 30$ years old & 8 & 4.9 \\
\hline 2 & $31-40$ years old & 41 & 25.2 \\
\hline 3 & $41-50$ years old & 43 & 26.4 \\
\hline 4 & $\geq 50$ years old & 71 & 43.6 \\
\hline \multicolumn{4}{|c|}{ GENDER } \\
\hline 1 & Male & 104 & 63.8 \\
\hline 2 & Female & 59 & 36.2 \\
\hline \multicolumn{4}{|c|}{ EDUCATIONAL BACKGROUND } \\
\hline 1 & Master & 106 & 65.0 \\
\hline 2 & Doctor & 57 & 35.0 \\
\hline \multicolumn{4}{|c|}{ TENURESHIP } \\
\hline 1 & One period & 129 & 79.1 \\
\hline 2 & Two periods & 30 & 18.4 \\
\hline 3 & Three periods & 4 & 2.5 \\
\hline
\end{tabular}


Table 2. Model validity and reliability

\begin{tabular}{|c|c|c|c|c|c|}
\hline Variables & Indicators & Outer loading & $\begin{array}{l}\text { Composite } \\
\text { reliability }\end{array}$ & $\begin{array}{c}\text { Cronbach's } \\
\text { alpha }\end{array}$ & AVE \\
\hline \multirow{4}{*}{ HRM practices (X1) } & $X 1.1$ & 0.768 & \multirow{4}{*}{0.835} & \multirow{4}{*}{0.671} & \multirow{4}{*}{0.656} \\
\hline & $\mathrm{X} 1.2$ & 0.823 & & & \\
\hline & $\mathrm{X} 1.3$ & 0.813 & & & \\
\hline & $\times 1.4$ & 0.737 & & & \\
\hline \multirow{4}{*}{ Organizational culture (X2) } & $\times 2.1$ & 0.733 & \multirow{4}{*}{0.872} & \multirow{4}{*}{0.765} & \multirow{4}{*}{0.726} \\
\hline & $\times 2.2$ & 0.815 & & & \\
\hline & $\times 2.3$ & 0.748 & & & \\
\hline & $\times 2.4$ & 0.701 & & & \\
\hline \multirow{4}{*}{ Knowledge management (Y1) } & Y1.1 & 0.831 & \multirow{4}{*}{0.890} & \multirow{4}{*}{0.813} & \multirow{4}{*}{0.736} \\
\hline & Y1.2 & 0.725 & & & \\
\hline & Y1.3 & 0.905 & & & \\
\hline & Y1.4 & 0.879 & & & \\
\hline \multirow{7}{*}{ Organizational performance (Y2) } & Y2.1 & 0.761 & \multirow{7}{*}{0.883} & \multirow{7}{*}{0.781} & \multirow{7}{*}{0.739} \\
\hline & Y2.2 & 0.687 & & & \\
\hline & Y2.3 & 0.659 & & & \\
\hline & Y2.4 & 0.621 & & & \\
\hline & Y2.5 & 0.862 & & & \\
\hline & Y2.6 & 0.887 & & & \\
\hline & Y2.7 & 0.881 & & & \\
\hline
\end{tabular}

\subsection{Validity and reliability}

A PLS model requires two stages of analysis, which is adequacy of the measures and structural model. The former is assessed by evaluating the reliability of the individual measures and the discriminant validity of the constructs (Hulland, 1999). Item reliability is assessed by examining the loadings of the measures on their corresponding construct. Each item loadings hold approach or exceed 0.707 (Carmines \& Zeller, 1979). Table 3 shows that all individual measures are reliable, since all item loadings exceed the value of 0.707 .

As to composite reliability, Table 3 shows that all constructs are reliable, since the composite reliability values are over 0.7 and even over 0.8 (Nunnally, 1978). In fact, the lowest value of composite reliability is 0.835 .

For discriminant validity, the average variance of manifest variables extracted by constructs (AVE) is at least 0.5 . Table 2 shows that the lowest value of AVE is 0.656 , that is over the minimum value of 0.5 .

\subsection{Hypotheses testing}

The results oh hypotheses testing reveal that there is a direct relationship between organizational culture and organizational performance. However, this effect does not occur on the relationship between organizational culture and $\mathrm{OCB}$, and that between $\mathrm{OCB}$ and organizational performance. It can be seen from path coefficient values, $t$-statistic and probability values. Table 3 presents the summary.

The effect of human resource management practice on knowledge management is positive. Its path coefficient is 0.449 and $t$-statistic is $6.239(p<0.05)$ revealing the fact that human resource management has a significant effect on

Table 3. The analytical results of direct effects

\begin{tabular}{|c|c|c|c|c|}
\hline Relationships & $\begin{array}{c}\text { Path } \\
\text { coefficients }\end{array}$ & $\begin{array}{l}\text { Standard } \\
\text { deviation }\end{array}$ & t-stat & $\mathbf{P}$ \\
\hline HRM practices $\rightarrow$ knowledge management & 0.449 & 0.072 & 6.239 & 0.000 \\
\hline Organizational culture $\rightarrow$ knowledge management & 0.442 & 0.070 & 6.343 & 0.000 \\
\hline HRM practices $\rightarrow$ organizational performance & 0.511 & 0.102 & 5.010 & 0.000 \\
\hline Organizational culture $\rightarrow$ organizational performance & 0.108 & 0.095 & 1.139 & 0.255 \\
\hline Knowledge management $\rightarrow$ organizational performance & 0.243 & 0.092 & 2.630 & 0.009 \\
\hline
\end{tabular}


knowledge management. The improved human resources management leads to better knowledge management.

The effect of organizational culture on knowledge management is positive. Its path coefficient is 0.442 and $t$-statistic is $6.343(p<0.05)$, confirming that organizational culture has a significant effect on knowledge management. The more suitable organizational culture leads to better knowledge management.

The effect of human resources management practice on organizational performance is positive. Its path coefficient is 0.511 and $t$-statistic is 5.010 $(p<0.05)$, confirming that human resources management practice has a significant effect on organizational performance. Improved human resources management practice leads to organizational performance.

The effect of organizational culture on organizational performance is positive. Its patch coefficient is 0.108 and $t$-statistic is 1.139 ( $p>0.05)$, confirming that organizational culture has an insignificant effect on organizational performance. The more suitable organizational culture does not necessarily lead to organizational performance.

The effect of knowledge management on organizational performance is positive. Its path coefficient is 0.243 and $t$-statistic is $2.630(p<0.05)$, confirming that better knowledge management has a significant effect on improved organizational performance. The increased knowledge management will increase organizational performance.

\subsection{The mediating test results}

The size of indirect effect of human resources management practices on organizational performance is 0.109 . It means that knowledge man- agement is crucial in mediating the relationship between human resources management practices and organizational performance. Since both human resources management practices and knowledge management have a significant direct effect on organizational performance, thus, knowledge management serves as partial mediator between human resources management practices and organizational performance.

The size of indirect effect of organizational culture on organizational performance is 0.107 . It means that knowledge management might mediate the relationship between organizational culture and organizational performance. The insignificant effect of organizational culture on organizational performance makes knowledge management serves as a full mediator in the relationship of two variables.

Partial mediation served by knowledge management in the relationship between human resources management practices and organizational performance indicates that HRD practices are instrumental in achieving organizational performance. The right recruitment, motivation maintenance that covers salary, clear career prospect, merit-based promotion, appreciation and recognition to individual's works, and organizational support, among others, would encourage all individuals to contribute their best to their works that might lead to heightened organizational performance. The atmosphere of university as a place of knowledge growth, dispersal, transmission, and exchange should be maintained if organizational performance is to achieve. It also indicates that people in universities continuously commit themselves to their works even though knowledge management is still applied in a limited manner.

Full mediation served by knowledge management in the relationship between organizational culture

Table 4. The results of indirect effects

\begin{tabular}{l|c|c|c}
\hline \multicolumn{1}{c}{ Relationships } & $\begin{array}{c}\text { Path } \\
\text { coefficients }\end{array}$ & $\begin{array}{c}\text { Standard } \\
\text { deviation }\end{array}$ & t-stat \\
\hline HRM practices $\rightarrow$ knowledge management & - & - & P \\
Organizational culture $\rightarrow$ knowledge management & - & - & - \\
HRM practices $\rightarrow$ organizational performance & 0.109 & 0.043 & - \\
Organizational culture $\rightarrow$ organizational performance & 0.107 & 0.049 & - \\
Knowledge management $\rightarrow$ organizational performance & - & - & 0.011 \\
\hline
\end{tabular}


and organizational performance indicates that organizational culture does not prevent people from giving best contribution to the works. They continuously adapt themselves to make the organization stay in a good performance. It implies that transition from learning organization to knowledge and research organization still runs even in a slow manner. If it is the case, knowledge management is required to buffer the effort to achieve heightened performance.

\section{DISCUSSION}

University is one of knowledge-based organizations that rely on human capital for their growth. Human resources and their management is the key for their competitiveness. Thus, the role human resources play in achieving organizational performance is highly vital. Even huge capital-based corporations owe their fame from individual's intellectual capital. We can name a few, among others, such as Apple with Steve Jobs figure, or Facebook with Mark Zuckerberg, or others with human resources capital as a whole.

Knowledge sharing is one of human resources management practices' outcomes. It tightens relationships, widens network, and accumulate knowledge. Other outcomes include innovativeness, increased productivity rate, knowledge acquisition, citizenship behavior, and the like. It derives from human capital. Its proper management will buffer excellent performance of knowledge management. Recruitment, human resources training and development play significant part in ensuring optimal knowledge management that covers the contribution, creation, sharing, and distribution of knowledge. The importance of human resource management practice is evident not only from its effect on knowledge management, but also from its direct effect on organizational performance. Put in another words, it can still significantly contribute to organizational performance, even if the support from knowledge management is overlooked. However, because of its effect on knowledge management, it also can affect organizational performance through knowledge management. Thus, to ensure the achievement of organizational performance, organization should start all operations from human resources management. It explains the partial role knowledge management plays in the relationship between human resources management practices and organizational performance. Universities should give great attention to human resources management practices to achieve exceptional organizational performance.

In the meantime, knowledge management serves as a full mediator in the relationship between organizational culture and organizational performance. It means that organizational culture does not necessarily lead to organizational performance. The insignificance effect of organizational culture on organizational performance is partly due to age. According to data, most of department administrators' age is over 50 (43.6\%). It indicates that people over 50 tend to be tardy, submissive to any difficult challenges, and avoid making breakthrough that make most of them unable to capitalize on organizational culture. Such hindrances as the time-consuming nature of post-graduate study and high cost are other factors that prevent organizational culture from affecting the organizational performance. This explains that majority of university administrators are only master graduated, and that market culture is not optimally developed. Without overlooking other cultural type's contributions to organizational performance, market culture particularly pertains to competitiveness and goal achievement. In another words, when it comes to organizational performance, market culture must sufficiently develop. Indonesian university commonly grows in family-like culture full with regulations. Some changes in culture, though difficult, might enable for direct effect on organizational performance.

Based on the present results, culture should enable for knowledge development for it to have an effect on organizational performance. Thus, knowledge management is one route that organizational culture should take to achieve increased organizational performance.

\section{FUTURE RESEARCH}

Qualitative research to explore the nature of and reasons behind the insignificant effect of organizational culture on organizational performance in private University of Malang is important to 
enrich knowledge of the relationship. The same is true for quantitative research that explores each organizational culture dimension effect on organizational performance to find out respective degree of effect.
Moderating variables are also worth exploring, as each university has its own characteristics such as recruitment style, career paths, leadership styles and others. Respondents could involve both head of department and secretary of department.

\section{CONCLUSION}

The above results provide a base for us to draw some inferences. For one, human resources management practices have a significant effect on organizational performance. It means that increased organizational performance requires a reliable management on all levels and capability for optimum human resources management practices. Another is that human resources management practices have a significant effect on knowledge management. It means that quality human resources practices would increase knowledge management. Put all together, it brings us to result that knowledge management mediates the effect of human resources practices on organizational performance. For organizational performance to improve, there should be a sound knowledge management supported by well managed human resources management practices. Since human resources management practices have a direct significant effect on organizational performance, knowledge management serves as a partial mediation between the two.

Organizational culture has insignificant effect on organizational performance. It means that well developed organizational culture does not necessarily lead to improved organizational performance. However, organizational culture has a significant effect on knowledge management. It means that well developed organizational culture greatly supports knowledge management. Put all together, it leads us to result that knowledge management mediates the effect of organizational culture on organizational performance. For organizational performance to change, lecturers should have sound knowledge management supported by organizational culture. Since organizational culture does not have a significant effect on organizational performance, knowledge management serves as a full mediation between the two.

Knowledge management itself has a significant effect on organizational performance. It means that the increase of knowledge management would boost organizational performance.

\section{REFERENCES}

1. Absah, Y. (2008). Pembelajaran Organisasi: Strategi Membangun Kekuatan Peguruan Tinggi. Jurnal Manajemen Bisnis, 1(1), 33-41. Retrieved from https:// www.researchgate.net/publication/48379174_Pembelajaran_Organisasi_Strategi_Membangun_ Kekuatan_Perguruan_Tinggi

2. Adhikari, D. R. (2010). Knowledge management in academic institutions. International Journal of Educational Management, 24(2), 94-104. https://doi. org/10.1108/09513541011020918

3. Al Saifi Said Abdullah (2015). Positioning organizational culture in knowledge management research. Journal of Knowledge
Management, 19(2), 164-189. http://dx.doi.org/10.1108/JKM07-2014-0287

4. Amin, M., Khairuzzaman Wan Ismail, W., Zaleha Abdul Rasid, S., \& Daverson Andrew Selemani, R. (2014). The impact of human resource management practices on performance. The TQM Journal, 26(2), 125-142. https://doi. org/10.1108/TQM-10-2011-0062

5. Amir, Faisal, Muhammad (2010). Membangun Kesiapan Sistem Penjaminan Mutu Eksternal (SPME) Bagi Perguruan Tinggi di Indonesia. Disampaikan dalam lokakarya persiapan SPME bagi fakultas ekonomi di lingkungan PT.
6. Arwildayanto (2013). Manajemen Sumber Daya Manusia Perguruan Tinggi: Pendekatan Budaya Kerja Dosen Profesional. Bandung: Alfabeta.

7. Bayat, R. F. (2011). Impact on the Productivity of Human Resources Management, Performance Evaluation. Australian Journal of Basic and Applied Sciences, 5(12), 1629-1635.

8. Björkman, I., \& Budhwar, P. (2007). (2007). When in Rome ... ?: Human resource management and the performance of foreign firms operating in India. Employee Relations, 29(6), 595-610. https://doi. org/10.1108/01425450710826104 
9. Byrne, B. M. (2013). Structural equation modeling with AMOS: Basic concepts, applications, and programming (2nd ed.) (396 p.). Taylor and Francis. https://doi. org/10.4324/9780203805534

10. Carmines, E. G., \& Zeller, R. A. (Eds.) (1979). Reliability and Validity Assessment. London: Sage Publication.

11. Dessler, G. (2011). Manajemen sumber daya manusia. Jakarta: Indeks Publisher.

12. Fong, C. Y., Ooi, K. B., Tan, B. I., Lee, V. H., \& Chong, A. Y. L. (2011). HRM practices and knowledge sharing: An empirical study. International Journal of Manpower, 32(5/6), 704-723. https://doi. org/10.1108/01437721111158288

13. Gholami, M. H., Asli, M. N., Nazari-Shirkouhi, S., \& Noruzy, A. (2013). Investigating the influence of knowledge management practices on organizational performance: An empirical study. Acta Polytechnica Hungarica, 10(2), 205-216. Retrieved from https://www.researchgate.net/ publication/287842731_Investigating_the_Influence_of_Knowledge_Management_Practices_on_ Organizational_Performance_An_ Empirical_Study

14. Gibson, J. L., Ivancevich, J. M., Donelly, J. H., \& Konopaske, R. (2012). Organizations Behavior, Structure, Processes. Journal of Chemical Information and Modeling, 53, 367. Retrieved from https://www.mheducation.com/ highered/product/organizationsbehavior-structure-processes-gibson-ivancevich/M9780078112669. html

15. Hatch, N. W., \& Dyer, J. H. (2004) Human capital and learning as a source of sustainable competitive advantage. Strategic Management Journal, 25(12), 1155-1178. https://doi.org/10.1002/smj.421

16. Homburg, C., Krohmer, H., \& Workman, J. P. (1999). Strategic consensus and performance: The role of strategy type and market-related dynamism. Strategic Management Journal, 20(4), 339-357. https://doi.
org/10.1002/(SICI)10970266(199904)20:4<339::AIDSMJ29>3.0.CO;2-T

17. Hulland, J. (1999). Use of partial least squares (PLS) in strategic management research: a review of four recent studies. Strategic Management Journal, 20(2), 195-204. https://doi. org/10.1002/(SICI) 10970266(199902)20:2<195::AIDSMJ13>3.3.CO;2-Z

18. Idris, S. A. M., Wahab, R. A., \& Jaapar, A. (2015). Corporate Cultures Integration and Organizational Performance: A Conceptual Model on the Performance of Acquiring Companies. Procedia - Social and Behavioral Sciences, 172, 591595. https://doi.org/10.1016/j. sbspro.2015.01.407

19. Jimenez-Jimenez, D., \& Sanz-Valle, R. (2013). Studying the effect of HRM practices on the knowledge management process. Personnel Review, 42(1), 28-49. https://doi. org/10.1108/00483481311285219

20. Karpagam, U. P. L., \& Suganthi, P. L. (2010). A Strategy Framework for Managing Higher Education Institutions. Advances in Management, 3(10). Retrieved from https://ideas.repec.org/a/ mgn/journl/v3y2010i10a2.html

21. Lin, C. Y., \& Kuo, T. H. (2007). The mediate effect of learning and knowledge on organizational performance. Industrial Management and Data Systems, 107(7), 1066-1083. https://doi. org/10.1108/02635570710816748

22. Mahsun, M. (2007). Pengukuran Kinerja Sektor Publik. Jakarta: BPFE Publisher.

23. Manafi, M., \& Subramaniam, I. D. (2015). The role of the perceived justice in the relationship between human resource management practices and knowledge sharing: A study of Malaysian university lecturers. Asian Social Science, 11(12), 131-143. https://doi. org/10.5539/ass.v11n12p131

24. Mathis, R. L., \& Jackson, J. H. (2006). Human Resource Management. Alih Bahasa. Jakarta: Salemba Empat.
25. Moideenkutty, U., Al-Lamki, A., \& Murthy, Y. S. R. (2011). HRM practices and organizational performance in Oman. Personnel Review, 40(2), 239-251. https://doi. org/10.1108/00483481111106101

26. Mondy, R. W. (2010). Human Resource Management (11th ed.). Pearson/Prentice Hall, Upper Saddle River, NJ.

27. Naranjo-Valencia, J. C., JiménezJiménez, D., \& Sanz-Valle, R. (2016). Studying the links between organizational culture, innovation, and performance in Spanish companies. Revista Latinoamericana de Psicologia, 48(1), 30-41. https://doi. org/10.1016/j.rlp.2015.09.009

28. Nunnally, J. (1978). Psychometric Theory (2nd ed.). New York: McGraw-Hill.

29. Pension, K., Nyasha, M., Sheiller, M., \& Vhuramai, C. (2013). Impact of Knowledge Management on Organizational Performance: A Case Study of Grain Marketing Board (GMB). Greener Journal of Business and Management Studies, 3(6), 270278. Retrieved from http://www. gjournals.org/GJMBS/PDF/2013/ August/071513733\%20Katsuro\%20et\%20al.pdf

30. Pinho Carlos, J., Paula Rodrigues, A., \& Dibb, S. (2014). The role of corporate culture, market orientation and organizational commitment in organizational performance. Journal of Management Development, 33(4), 374-398. https://doi.org/10.1108/ JMD-03-2013-0036

31. Prabowo, H. (2010). Knowledge Management di Perguruan Tinggi. Binus Business Review, 1(2), 407. https://doi.org/10.21512/bbr. v1i2.1087

32. Quresh, T. M., Akbar, A., Khan, M. A., Sheikh, R. A., \& Hijazi, S. T. (2010). Do human resource management practices have an impact on financial performance of banks? African journal of business management, 4(7), 1281-1288. Retrieved from https://academicjournals.org/ journal/AJBM/article-full-textpdf/5FE192E25870 
33. Randhawa, G. (2007). Human Resource Management. Atlantic Publishers and Distributors Ltd.

34. Robbins, S. P., \& Timothy, A. J. (2008). Perilaku Organisasi (12th ed.). Jakarta: Salemba Empat.

35. Saeed, R., Lodhi, R. N., Iqbal, A., \& Sandhu, M. A. (2013). The Effect of Human Resource Management Practices on Organization's Performance. Middle- East Journal of Scientific Research, 16(11), 1548-1556. http://dx.doi.org/10.5829/idosi. mejsr.2013.16.11.12077

36. Schein, E. H. (2004). Organizational Culture and Leadership. Jossey-Bass, Wiley.

37. Sekaran, U. (2006). Research method of business: A skill-building approach. John Wiley \& Sons, Inc. Retrieved from https://www.wiley. com/en-us/Research + Methods $+\mathrm{F}$ or+Business $\% 3 \mathrm{~A}+\mathrm{A}+$ Skill+Build ing + Approach $\% 2 \mathrm{C}+7 \mathrm{th}+$ Edition -p-9781119266846

38. Serban, A. M., \& Luan, J. (2002). Overview of Knowledge Management. New Directions for Institutional Research, 113, 5-16. https://doi.org/10.1002/ir.34
39. Singh, K. (2004). Impact of HR practices on perceived firm performance in India. Asia Pacific Journal of Human Resources, 42(3), 301-317. https://doi. org/10.1177/1038411104048170

40. Suwatno, D., \& Juni, P. (2013). Manajemen SDM dalam Organisasi Publikdan Bisnis. Bandung: Alfabeta.

41. Tseng, S. M. (2010). The correlation between organizational culture and knowledge conversion on corporate performance. Journal of Knowledge Management, 14(2), 269-284. https://doi. org/10.1108/13673271011032409

42. Uha, Ismail N. (2013). Budaya Organisasi Kepemimpinan \& Kinerja (1st ed.). Surabaya: Kencana Prenada Media Group.

43. Valmohammadi, C., \& Ahmadi, M. (2015). The impact of knowledge management practices on organizational performance: A balanced scorecard approach. Journal of Enterprise Information Management, 28(1), 131-159. https://doi.org/10.1108/JEIM-092013-0066
44. Vivares-Vergara, J. A., SaracheCastro, W. A., \& NaranjoValencia, J. C. (2016). Impact of human resource management on performance in competitive priorities. International Journal of Operations and Production Management, 36(2), 114134. https://doi.org/10.1108/ IJOPM-11-2013-0484

45. Wibowo (2011). Budaya Organisasi: sebuah kebutuhan untuk meningkatkan kinerja jangka. Panjang. Jakarta: Rajawali Pers.

46. Yazhou, W., \& Jian, L. (2012). The Mediating Effect of Knowledge Management Orientation on Human Resource Management Practices and Organizational Performance. Advances in information Sciences and Service Sciences (AISS), 4(19).

47. Yesil, S., \& Kaya, A. (2013). The Effect of Organizational Culture on Firm Financial Performance: Evidence from a Developing Country. Procedia - Social and Behavioral Sciences, 81, 428437. https://doi.org/10.1016/j. sbspro.2013.06.455 